\title{
Flexible Fuel Vehicles: Providing a Renewable Fuel Choice
}

Today, more than 5 million vehicles on U.S. highways are flexible fuel vehicles (FFVs). These vehicles can operate on E85-a blend of $85 \%$ ethanol and 15\% gasoline.

The ethanol component of this renewable fuel offers significant advantages. It is manufactured in the United States, made from home-grown feedstocks, and is cleaner burning than gasoline.

\section{What is an FFV?}

An FFV, as its name implies, has the flexibility of running on more than one type of fuel. FFVs can be fueled with unleaded gasoline, E85, or any combination of the two. Like conventional gasoline vehicles, FFVs have a single fuel tank, fuel system, and engine. And they are available in a wide range of models such as sedans, pickups, and minivans. These light-duty FFVs are designed to run on at least $15 \%$ gasoline in the fuel, mainly to ensure they start in cold weather.
FFVs differ from conventional vehicles in some ways. They are equipped with modified components designed specifically to be compatible with ethanol's chemical properties. In the car illustration below, major modification requirements for FFVs are described. These modifications ensure seamless operation and a long useful life across a wide range of ethanol blends.

Clean Cities posts a list of alternative fuel vehicles, including FFVs, on its Alternative Fuels Data Center (AFDC) Web site. To find out about available models, visit www.eere.energy.gov/afdc/ afv/afdc_vehicle_search.php and choose the current model year.

\section{Can existing vehicles be converted to FFVs?}

Converting a conventional gasoline vehicle to one that runs on E85 is certainly technically possible. However, at this time only originally manufactured FFVs are certified by the Environmental Protection Agency (EPA) to run on E85. FFV

\section{Flexible Fuel Vehicle Features}

Engine calibration updates: Fueling and spark advance calibrations directed by vehicle computer and software to optimize combustion, enable cold start, and meet emissions requirements

\section{Insulated wiring: Made from} special materials to handle ethanol's increased conductivity and corrosiveness
Fuel pump assembly: In-tank components made from ethanol-compatible materials; larger capacity fuel pump to deliver more fuel to compensate for ethanol's lower energy density
Updated piston rings, cylinder heads, valve seats, and valves: Special materials used to minimize wear from ethanol's alcohol properties, which wash lubrication from parts

Fuel sensor: Automatically senses the composition of fuel to adjust for ethanol blends
Updated fuel injectors: Made from ethanol-compatible materials; designed to deliver greater fuel volume required by ethanol's lower energy density
Fuel rail and fuel lines: Made from ethanolcompatible materials; designed to handle increased fuel volume requirements to compensate for ethanol's lower energy density
Fuel filler neck: Anti-siphon and spark arrestor features included to handle ethanol's increased conductivity 
conversions need to be done by authorized companies and require certification by the EPA or the California Air Resources Board. In addition, converting a vehicle to E85 may affect its warranty.

For more information on the vehicle conversion process, refer to the EPA's Updated Certification Guidance for Alternative Fuel Converters on its Web site at www.epa.gov/otaq/cert/ dearmfr/cisd0602.pdf.

\section{Does E85 affect vehicle performance?}

FFVs operating on E85 generally handle and perform just as well as when fueled with gasoline. Sensors in the FFV system automatically prompt adjustments for fuel composition, so emissions and standard performance areas such as power and acceleration are not significantly affected by E85. One difference between E85 and gasoline, however, is fuel economy. Ethanol contains less energy per gallon, which translates into a reduction in fuel economy compared to gasoline. No matter what type of fuel is used, however, fuel mileage is affected by driving habits, weather, ethanol blend in the tank, and other factors.

Standard testing results for fuel economy of FFVs and their gasoline counterparts are posted on the combined EPA and U.S. Department of Energy Web site at www.fueleconomy.gov.

\section{What are the costs and benefits of using E85?}

Special features enabling vehicles to run on E85 can add a minimal cost to their purchase price. Often these features are standard or even offered as a no-cost option. Because they have a solid performance history, manufacturers provide standard warranties for FFVs equal to those for gasoline vehicles at no additional charge.

Fuel, however, may be a cost factor. E85's reduced fuel economy compared to gasoline, as explained in the previous section, can increase fuel costs. But this cost differential is highly variable because it is based on ethanol and gasoline price differences. Like gasoline, ethanol prices fluctuate and are set based on market supply and demand. This variability means that a driver may or may not experience a difference in overall fuel costs, depending on local pump prices. To compare the price of fueling with E85 versus gasoline, use the AFDC's Flexible Fuel Vehicle Cost Calculator at www.eere. energy.gov/fleetguide/cost_anal.php?0/E85 *Flex ${ }^{*}$ Fuel.

Even though FFV fuel economy when operating on E85 is less than conventional fuel, E85 provides reductions in life-cycle greenhouse gas emissions because of its renewable source component. ${ }^{1}$ Recent, limited tests indicate that E85 use results in reduced $\mathrm{CO}_{2}$ emissions, evaporative emissions, and specific harmful toxics such as benzene and 1,3 butadiene. However, E85 may increase aldehyde emissions, which are toxic pollutants. ${ }^{2}$ The EPA, National Renewable Energy Laboratory, and Coordinating Research Council (CRC) are analyzing E85 emissions to expand the understanding of their impacts.

\section{How are FFVs identified?}

A look inside the fuel door quickly identifies FFVs. Since September 2006, the Energy Policy Act of 2005 requires auto manufacturers to place a label inside the FFV fuel compartment that states the vehicle can run on either E85 or gasoline. Flexible-fuel capability also is outlined in the owner's manual and encoded in the vehicle identification number, or VIN. To help determine if an older vehicle is E85 compatible, visit the National Ethanol Vehicle Coalition Web page on flexible fuel vehicles at www.e85fuel.com/e85101/ flexfuelvehicles.php.

\section{Where are E85 stations located?}

Stations offering E85 continue to increase across the nation. At the end of 2006, more than 1,000 stations in at least 45 states sold E85. To find E85 stations throughout the country, check out the Alternative Fuel Station Locator at www.eere.energy.gov/afdc/infrastructure/locator.html, a database maintained by the AFDC. This easy-to-use database allows users to plot routes either across town or across the nation, showing E85 stations along the way.

\footnotetext{
${ }^{1}$ Wang, Michael. Ethanol: The Complete Energy Lifecycle Picture, Argonne National Laboratory, March 2007.
}

2 Whitney, Kevin (Southwest Research Institute); Fernandez, Tony (U. S. Environmental Protection Agency). "Characterization of Cold Temperature VOC and PM Emissions from Flex Fuel Vehicles Operating on Ethanol Blends." Presented at the 17th CRC On-Road Vehicle Emissions Workshop, March 26-28, 2007

\section{Resources}

Alternative Fuels Data Center: www.eere.energy.gov/afdc/altfuel/ethanol.html American Coalition for Ethanol: www.ethanol.org Clean Cities: www.eere.energy.gov/cleancities Clean Fleet Guide: www.eere.energy.gov/fleetguide E85 Fleet Toolkit: www.eere.energy.gov/afdc/e85toolkit Environmental Protection Agency: www.epa.gov/otaq/consumer/fuels/ altfuels/altfuels.htm

Fuel Economy: www.fueleconomy.gov

National Ethanol Vehicle Coalition: www.e85fuel.com

Renewable Fuels Association: www.ethanolrfa.org

\footnotetext{
Sponsored by the U.S. Department of Energy

Energy Efficiency and Renewable Energy

FreedomCAR and Vehicle Technologies Program

For more information contact: EERE Information Center 1-877-EERE-INF (1-877-337-3463) www.eere.energy.gov

A Strong Energy Portfolio for a Strong America

Energy efficiency and clean, renewable energy will mean a stronger economy, a cleaner environment, and greater energy independence for America. Working with a wide array of state, community, industry, and university partners, the U.S. Department of Energy's Office of Energy Efficiency and Renewable Energy invests in a diverse portfolio of energy technologies.

DOE/GO-102007-2431 • May 2007
}

\section{Prepared by the National Renewable Energy Laboratory (NREL) \\ NREL is a U.S. Department of Energy National Laboratory Operated by Midwest Research Institute $\bullet$ Battelle}

Neither the United States government nor any agency thereof, nor any of their employees, makes any warranty, express or implied, or assumes any legal liability or responsibility for the accuracy, completeness, or usefulness of any information, apparatus, product, or process disclosed, or represents that its use would not infringe privately owned rights. Reference herein to any specific commercial product, process, or service by trade name, trademark, manufacturer, or otherwise does not necessarily constitute or imply its endorsement, recommendation, or favoring by the United States government or any agency thereof. The views and opinions of authors expressed herein do not necessarily state or reflect those of the United States government or any agency thereof.

Printed with a renewable-source ink on paper containing at least $50 \%$ wastepaper, including $10 \%$ postconsumer waste. 